\title{
PERAN WALI KELAS, BIMBINGAN KONSELING DAN ORANG TUA DALAM MEMBENTUK PENDIDIKAN KARAKTER DI SMA NEGERI 7 BALIKPAPAN
}

\author{
Masniari Siregar ${ }^{1}$, Casmudi $^{2}$, Tri Astuti Nur'aini ${ }^{3}$ \\ Universitas Balikpapan ${ }^{1}$,Universitas Balikpapan ${ }^{2}$, Universitas Balikpapan ${ }^{3}$ \\ Pos-el : Masniarirasmie05@,gmail.com¹, $\underline{\text { casmudi@uniba-bpn.ac.id }{ }^{2}}, \underline{\text { tri.astuti@,uniba-bpn.ac.id }}$
}

\begin{abstract}
ABSTRAK
Tujuan penelitian ini untuk mengetahui peran wali kelas, guru bimbingan konseling dan orang tua dalam membentuk pendidikan karakter di SMA Negeri 7 Balikpapan. Analisis data menggunakan triangulasi data yaitu wawancara, observasi dan dokumentasi.Hasil penelitian menunjukkan peran wali kelas dengan menerapkan disiplin di kelas dengan sangsi yang mendidik, memberikan teladan dan melakukan pendekatan kepada orang tua dan siswa dengan membuat program-program yang bersifat mendidik. Peran Guru Bimbingan Konseling dengan mendukung program-program sekolah seperti peningkatan disiplin siswa, dan peningkatan kegiatan keagamaan dengan melakukan pendekatan-pendekatan yang disesuaikan dengan karakter siswa dan juga pendekatan kepada orang tua untuk mengatasi masalah yang terjadi pada siswa. Peran orang tua dengan memulai pendidikan agama di rumah seperti sholat-mengaji, mengajarkan anak untuk bersikap jujur, rajin belajar dan bekerjasama dengan pihak sekolah dalam mengatasi masalah yang terjadi pada anak.
\end{abstract}

Kata Kunci: Wali Kelas, Guru Bimbingan Konseling, Orang Tua, Pendidikan

Karakter.

\section{ABSTRACT}

The purpose of this study was to determine the role of homeroom teacher, counseling guidance teacher and parents in shaping character education in Balikpapan 7 Public High School. Data analysis uses data triangulation, namely interviews, observation and documentation. The results of the study show the role of the homeroom teacher by applying discipline in the classroom with sanctions that educate, set an example and approach parents and students by making programs that are educational. The Role of Counseling Guidance Teachers by supporting school programs such as increasing student discipline, and increasing religious activities by carrying out approaches that are tailored to the character of students and also approaches to parents to overcome problems that occur in students. The role of parents by starting religious education at home such as praying, teaching children to be honest, studying diligently and cooperating with the school in dealing with problems that occur in children.

Keywords: Guardian Class, Teacher Counseling Guidance, Parents, Education Character.

Jurnal Edueco Volume 2 Nomor 1 Juni 2019 


\section{PENDAHULUAN}

Bangsa Indonesia masih mengalami permasalahan yang sangat besar terkait karakter bangsa. Berbagai masalah yang muncul di masyarakat seperti korupsi, tawuran antar siswa, pelecehan seksual, berkembangnya faham-faham radikal yang mengancam persatuan bangsa. Itu semua sedikit menggambarkan sampai mana ketercapaian tujuan pendidikan nasional kita. Menaggapi hal ini, salah satu kajian yang banyak dibahas untuk mengatasi masalah karakter bangsa adalah pendidikan karakter.

Grand Design pendidikan karakter yang dikembangkan oleh Kemendiknas (2010), menyatakan bahwa pendidikan karakter merupakan proses pembudayaan dan pemberdayaan peserta didik agar memiliki nilai-nilai luhur dan perilaku berkarakter yang dilakukan melalui tri pusat pendidikan, yaitu pendidikan di keluarga, pendidikan di sekolah dan pendidikan di masyarakat.

Sekolah sebagai salah satu lembaga yang menyelenggarakan pendidikan formal mempunyai peranan yang sangat penting dalam usaha mendidik anakanak dan menjadikannya sebagai masyarakat yang berguna. Hal ini berarti sekolah turut pula bertanggung jawab atas tercapainya suatu tujuan yang telah ditetapkan. Pendidikan menurut Undang-Undang Sisdiknas, Tahun 2003, Bab.1, Pasal.1, Ayat.1, bahwa: "Pendidikan adalah usaha sadar dan terencana untuk mewujudkan suasana belajar dan proses agar peserta didik secara aktif mengembangkan potensi dirinya untuk memiliki kekuatan spiritual, keagamaan, pengendaliaan diri, kepribadiaan kecerdasan, akhlak mulia, serta keterampilan yang diperlukan dirinya, bangsa dan Negara (Maragustam, 2010, 120).

Hilangnya nilai-nilai pendidikan karakter ini sangat memprihatinkan. Mengingat hal tersebut maka pendidikan karakter sangat penting diberikan pada siswa di sekolah, demi terwujudnya tujuan pendidikan dan membentuk karakter siswa menjadi pribadi yang matang.

Untuk mewujudkan tercapainya program pendidikan karakter tersebut, perlu adanya sinergitas antara orang tua wali murid dengan wali kelas dan guru yang ada di sekolah untuk menemukan pola apa yang tepat untuk menerapkan nilai-nilai pendidikan karakter. Adapun salah satu nilai karakter yang perlu dikembangkan di sekolah, kerjasama antara orang tua, wali kelas dan guru dapat membantu siswa mengembangkan kemampuan dirinya menjadi manusia yang berbudi luhur, cerdas dan kreatif (Mustari, 2014 : 35).

Selain sekolah, keluarga memiliki peran yang sangat penting dalam membentuk kepribadian anak. Kepincangan dalam keluarga membawa akibat dalam kehidupan disekolah dari anak-anaknya. Anak-anak sering merasa murung, putus asa,disiplin sekolah tak diindahkan lagi, bergaul yang tak terkontrol, bermain diluar batas sehingga tugas-tugas sekolahpun terabaikan, prestasi merosot, hasil nilai 
belajar rendah dan bahkan tidak naik kelas.

Pentingnya keterlibatan orang tua dalam pendidikan karakter erat kaitannya dengan peran keluarga. Keluarga merupakan lingkungan terdekat dengan siswa dan sebagian waktu siswa habis dalam lingkungan ini. Hal ini senada dengan pendapat Lickona yang menjelaskan bahwa keluarga merupakan tempat yang paling dekat untuk mendapatkan pembelajaran, Lickona juga menjelaskan bahwa prestasi seorang anak akan meningkat jika orang tuanya berada dirumah, memperoleh perawatan yang baik, keamanan, ada rangsangan untuk perkembangan intelektualitasnya, adanya dorongan orang tua dalam hal pengaturan diri, adanya pembatasan anak dalam menonton televisi, dan orang tua memonitor anak dalam hal mengerjakan PR.Lickona juga menjelaskan bahwa keluarga merupakan fondasi mengembangan intelektual dan moral (Lickona, 2014: 48). SMA Negeri 7 merupakan salah satu sekolah negeri yang ada di kota Balikpapan. Siswa-siswa yang masuk ke SMA Negeri 7 sebagian besar berasal dari wilayah Balikpapan Timur seperti daerah Sepinggan, Batakan, Teritip. Lamaru dan wilayah sekitarnya dimana karakter masyarakatnya sangat beragam dengan berbagai macam profesi pekerjaan, berasal dari suku yang berbeda serta pola hidup yang beragam, sehingga siswa yang masuk ke SMA Negeri 7 juga memiliki karakter dan kebiasaan yang berbedabeda. Pada saat peneliti melakukan observasi di sekolah peneliti menemukan ada beberapa siswa yang masih sering telambat datang ke sekolah dan ada beberapa dari sikap siswa yang kurang santun terhadap beberapa guru. Selama melakukan observasi peneliti juga menemukan kebiasaan siswa yang keluar kelas pada saat pelajaran berlangsung dengan alasan ke toilet tapi kembali nya cukup lama. Dapat disimpulkan masih masih ada karakter siswa yang kurang disiplin, jujur dan mematuhi peraturan. Dengan adanya masalah tersebut sekolah memiliki kewajiban untuk membentuk siswa yang berkarakter menjadi pribadi yang taat pada peraturan, taat beragama, berkepribadian kuat, mandiri, memiliki kemampuan dan mampu bersosialisasi.

\section{METODE PENELITIAN}

Pada penelitian ini, pendekatan yang digunakan adalah pendekatan kualitatif, karena penelitian ini didasarkan atas kesesuaian masalah yang ingin dipecahkan, maka metode yang digunakan adalah metode kualitatif.

\section{HASIL DAN PEMBAHASAN}

Hasil wawancara yang diperoleh dari kepala sekolah wali kelas diperoleh bahwa pendidikan karakter sudah diterapkan sejak sekolah menggunakan kurikulum 2013 yang diintegrasikan dalam mata pelajaran. Hal ini dapat dilihat dari kegiatan di sekolah misalnya 
sangsi yang diterapkan jika siswa melanggar peraturan, guru $\mathrm{BK}$ juga menjelaskan bahwa pendidikan karatkter sudah sejak lama dilaksanakan.

Hasil yang dapat dilihat dari penerapan pendidikan karakter ini adalah adanya perubahan dalam perilaku anak yang jauh berbeda dari sebelumnya dimana tingkat disiplin siswa sudah meningkat mencapai $90 \%$, keikutsertaan anak dalam kegiatan agama seperti sholat berjamaah yang merupakan program sekolah sudah meningkat, perilaku anak dalam menjaga kebersihan sekolah juga mengalami peningkatan.meskipun saat ini hasilnya belum maksimal hal tersebut dirasakan wajar karena latar belakang siswa yang berbeda-beda sehingga perlu penanganan yang berbeda pula. Program-program yang dilaksanakan sekolah terintegrasi dalam kegiatan pembelajaran dan penilaian siswa mengarah pada pendidikan karakter, dengan diterapkan kurikulum 2013 yang mengarah pada penerapan pendidikan karakter dapat memberikan peningkatan perilaku disiplin siswa dan pembentukan kepribadian yang lebih baik, siswa menjadi lebih perduli pada lingkungan sekitarnya.

Wali kelas melaksanakan perannya untuk mengarahkan siswa pada aturan yang sudah ditetapkan dan programprogram yang dibuat yang keseluruhannya adalah bertujuan untuk membentuk pendidikan karakter siswa. Program-program yang dibuat sekolah adalah sholat berjamaah untuk mendidik karakter ketuhanan, menjaga kebersihan lingkungan dengan menerapkan disiplin kepada siswa untuk menjaga kebersihan kelas dan lingkungan sekolah untuk menciptakan karakter mencintai lingkungan dan meningkatkan disiplin siswa, mengajarkan bagaimana siswa bersikap jujur dalam kegiatan belajar, sikap berani bertanggung jawab dan sikap tolong menolong, semuanya dilakukan untuk membentuk siswa yang berkarakter. Demikian juga guru BK sangat berperan dalam pembentukan pendidikan karakter karena hal ini juga merupakan tanggung jawab guru BK.

Hambatan yang dihadapi dalam penerapan pendidikan karakter anak adalah siswa berasal dari latar belakang keluarga yang berbeda-beda baik dari tingkat pendidikan orang tua, latar belakang ekonomi dan juga suku, anakanak membawa perilaku yang sudah terbentuk dari rumah dan lingkungan tempat tinggal sehingga wali kelas, guru BK ataupun guru harus mampu menyesuaikan diri dengan kondisi anakanak yang berbeda. Setiap anak akan ditangani dengan cara yang berbedabeda.

Untuk mengatasi masalah yang ada pihak sekolah seperti kepala sekolah, wali kelasa, guru BK membuat kebijakan yang berbeda-beda, ada yang harus diberikan ketegasan tapi sebagian besar kebijakan sekolah adalah memperlakukan mereka seperti anak sendiri, berkomunikasi dengan orang 
tua karena biasanya anak-anak yang bermasalah adalah anak-anak yang bermasalah dari rumah. Pendekatan harus dilakukan dengan siswa dan juga orang tua. Penerapan pendidikan karakter memiliki kelebihan dan kekurangan dimana kelebihannya adalah disiplin siswa menjadi meningkat karena penilaian karakter siswa masuk dalam peniliaian bidang studi, pendidikan karakter termasuk dalam pembelajaran sehingga memudahkan guru menerapkannya tetapi kekurangannya, penilaian yang begitu banyak mcukup menyita waktu guru dalam mengisi lembar penilaian, disamping tugas guru yang bergitu banyak. Jadi tugas menerapkan pendidikan karakter bukan hanya tugas wali kelas ataupun guru BK, guru bidang studi juga turut bertanggung jawab dalam membentuk karakter siswa. Dalam pembentukan karakter siswa, saat ini wali kelas, guru BK ataupun guru dihadapkan pada masalah kemajuan teknologi seperti hp yang hampir semua siswa memilikinya, pengaruh hp sangat besar bagi perilaku siswa, jika tidak digunakan dengan benar akan merusak moral siswa, oleh karena itu pihak sekolah sering melakukan razia hp di sekolah untuk menghindari atau mengurangi resiko penyalahgunaan $\mathrm{hp}$, meskipun hp juga bermanfaat jika digunakan dengan baik karena dalam kegiatan pembelajaran siswa juga dapat mencari materi tugas yang diberikan guru melalui hp. Yang penting adalah pengawasan yang dilakukan pihak sekolah terhadap penggunaan hp.

Faktor pendukung dari pelaksanaan pendidikan karakter ini adalah dukungan dari pihak sekolah seperti kepala sekolah, wali kelas, guru BK dan guru yang memegang bidang studi dan juga orang tua dimana saling bekerjasama untuk membentuk karakter siswa, selain itu adanya sarana prasarana yang menduung seperti mushola, taman sekolah, tempat olah raga, perpustakaan dan semua yang mendukung kegiatan belajar mengajar merupakan faktor pendukung pendidikan karakter siswa. Berdasarkan hal tersebut maka disimpulkan jika wali kelas, guru BK dan orang tua bekerjasama dengan baik maka akan meningkatkan dan mendukung pendidikan karakter siswa.

Wali kelas memiliki peran yang sangat penting bagi pembentukan karakter siswa, di SMAN 7 Balikpapan wali kelas sudah melaksanakan perannya dengan baik meskipun peran tersebut belum maksimal, tetapi terlihat bahwa angka disiplin siswa terus meningkat, jumlah siswa yang membolos berkurang dan pelanggaran disiplin juga berkurang. hal ini sesuai dengan penelitian yang dilakukan oleh Romayah Nur Puspitasari tahun 2017 dengan judul penelitian Peran Wali Kelas Sebagai Bimbingan Konseling Menanamkan Karakter Disiplin dan Jujur Pada Siswa Kelas Tinggi SDN 2 Kadipiro Tahun Ajaran 2016/2017. Hasil penelitian menunjukkan bahwa 1) 
Peran wali kelas sebagai pelaksana bimbingan konseling dalam menanamkan karakter disiplin dan jujur pada siswa yaitu: mendidik, mengarahkan, membimbing dan menuntun siswa untuk selalu menerapkan kedisiplinan dan kejujuran, memotivasi, sebagai fasilitator serta memberikan pelayanan terhadap segala masalah siswa. 2) Faktor yang mempengaruhi disiplin dan jujur: faktor yang mempengaruhi disiplin: faktor pembawaan, faktor minat, faktor pengaruh pola pikir, faktor contoh atau teladan, faktor nasihat, faktor lingkungan, dan faktor pengaruh kelompok. faktor yang mempengaruhi jujur: faktor pembawaan, faktor lingkungan, faktor pengaruh kelompok, dan faktor latihan. 3) Upaya menanamkan karakter disiplin dan jujur: dengan pembiasaan, contoh atau keteladanan, pengawasan atau kontrol, kantin kejujuran.

Dalam penerapan pendidikan karakter siswa menunjukkan bahwa guru BK sudah berupaya melakukan pendekatan-pendekatan kepada orang tua dan juga siswa, memberikan teladan yang baik, hasil penelitian ini sesuai dnegan penelitian yang dilakukan oleh Tri Aulia Rahmawati tahun 2016 dengan judul penelitian Peran Guru Bimbingan Konseling Dalam Membentuk Karakter Siswa di MTs negeri Yogyakarta II. Hasil penelitian ini mengetahui bentuk-bentuk kegiatan guru bimbingan konseling dalam kegiatan sekolah seperti membaca $\mathrm{Al}$
Quran, menghapal Asmaul Khusna, shalat Dhuha berjamaah, bersalaman atau berjabat tangan pada siswa yang baru datang dan membentuk karakter siswa melalui bimbingan individu dan kelompok. Orang tua memilii peran yang sangat penting bagi pendidikan karakter anak. Pembentukan karakter anak sudah bisa mulai dilihat oleh orang tua ketika anak masih berusia dini bahkan ketika masih berada didalam kandungan. Apabila orang tuanya berprilaku baik dalam mendidik anak, maka anaknya pun akan tumbuh dengan baik, begitupun sebaliknya. Anak akan menjadi nakal, manja bahkan suka melawan apabila pembentukan karakter anak yang dilakukan orang tuanya tak baik. Maka dari itu peran orang tua dalam pembentukan karakter anak begitu penting, apalagi di usia tahuntahun pertama bagi anak dalam mengarungi kehidupannya. Meskipun masih kecil, namun orang tua haruslah memberikan pendidikan dan mengajarkan anak tentang kebaikan, tak hanya itu bahkan para orang tua ini harus selalu berperilaku dan bertingkah baik pada si anak dan didepan anakanaknya, hal ini akan menjadi contoh yang direkam oleh memori anak semenjak masih kecil hingga ia dewasa. Anak sendiri adalah aset yang bisa menjadi penentu dalam keberlangsungan hidup manusia, kualitas serta kejayaan dari suatu bangsa di masa depan nanti. Oleh sebab itu, anak perlu dijaga agar bisa tumbuh dewasa secara optimal dan baik, 
menerima pendidikan yang baik supaya di masa depan bisa menjadi pribadi yang memiliki karakter baik dan berguna bagi semua orang, agamanya, nusa dan bangsa.

Karena itulah dibutuhkan peran Ayah dan Ibu dalam membentuk karakter sang anak tersebut. Keluarga merupakan sebuah lingkungan pertama bagi anak belajar tentang tingkah laku dan kehidupan hingga membentuk karakter mereka di masa depan. Keluarga bisa pula disebut sebagai primary group, bahkan ibu juga disebut sebagai madrasah atau sekolah pertama bagi sang anak sehingga benarbenar harus diperhatikan perkembangannya.

Penelitian yang menunjukkan pentingnya peran orangtua dalam pembentukan karakter anak ddidikung oleh penelitian yang dilakukan oleh Nency Permata Sari dengan judul penelitian peran orang tua dalam pembentukan karakter anak di kota Padang. Hasil penelitian yang diperoleh di lapangan bahwa orang tua memberikan penjelasan kepada anak tentang nilai-nilai religius agar anak paham dan mengerti apa itu religius dan mengetahui manfaat dari nilai religius. Selain itu, orang tua memberikan tugas kepada anak yang berhubungan dengan religius supaya anak lebih paham tentang religius dan bisa mengaplikasikan dalam kehidupan sehari-hari. Menurut Kurniawan (2013:85) nilai religius pada anak tidak cukup diberikan melalui pelajaran, pengertian, penjelasan, dan pemahaman. Penanaman nilai religius pada anak memerlukan bimbingan, yaitu usaha untuk menuntun, mengarahkan sekaligus mendapingi anak dalam halhal tertentu, terutama ketika anak merasakan ketidakberdayaannya atau ketika anak sedang mengalami masalah yang dirasakannya berat. Menurut Helmawati (2014:162) karakter yang paling utama yang hendaknya dibentuk pada anak dalam keluarga adalah karakter beriman dan bertakwa. Seperti yang telah diuraikan pada bab sebelumnya, karakter beriman yaitu orang yang hatinya lebih sibuk memikirkan dan memperhatikan apaapa yang diperintahkan oleh Allah guna dilaksanakan dan menjauhi apa-apa yang dilarang oleh-Nya. Menurut Mustari (2014:10) pendidikan agama harus dilakukan di rumah, di sekolah, di lingkungan masyarakat, di berbagai kelompok dan majelis. Pendidikan agama harus dilakukan dengan berbagai cara dan media.

Menurut peneliti, kehadiran orang tua dalam membimbing anak akan sangat berarti dan berkesan bagi anak-anaknya. Keteladanan orang tua juga merupakan nilai plus bagi anak yang akan meniru atau mendengarkan apa yang diperintahkan orang tua kepada anak-anaknya. Jadi, kebiasaankebiasaan yang baik yang ditampilkan oleh orang tua yang mencerminkan nilai-nilai religius akan mudah ditiru oleh anak dan didengar oleh anak serta 
diaplikasi dalam kehidupan sehariharinya.

\section{KESIMPULAN}

Peran wali kelas dalam membentuk pendidikan Berkarakter siswa di SMA Negeri 7 Balikpapan adalah dengan menerapkan disiplin di kelas dengan sangsi yang mendidik, memberikan teladan dan melakukan pendekatan kepada orang tua dan siswa dengan membuat program-program yang bersifat mendidik seperti mewajibkan anak-anak ikut sholat berjamaah di sekolah, membiasakan siswa membersihkan kelas dan menjaga kebersihan lingkungan sekolah.

Peran Guru BK dalam membentuk Pendidikan Berkarakter di SMA Negeri 7 Balikpapan adalah mendukung program-program sekolah seperti peningkatan disiplin siswa, dan peningkatan kegiatan keagamaan dengan melakukan pendekatanpendekatan yang disesuaikan dengan karakter siswa dan juga pendekatan kepada orang tua untuk mengatasi masalah yang terjadi pada siswa.

Peran orang tua dalam membentuk karakter pada siswa SMA Negeri 7 Balikpapan dengan memulai pendidikan agama di rumah seperti sholat- mengaji, mengajarkan anak untuk bersikap jujur, rajin belajar dan bekerjasama dengan pihak sekolah dalam mengatasi masalah yang terjadi pada anak.

Bagi Sekolah Perlu ditingkatkan lagi program-program yang ada di sekolah dan mengembangkan program-program lain yang dapat meningkatkan pendidikan karakter siswa misalnya kegiatan outbond yang dilaksanakan setiap tahun sekali karena dalam pendidikan outbond dapat membentuk karakter kejujuran, kerjasama, kepemimpinan, cinta lingkungan dan karakter lainnya.

Bagi Wali Kelas Perlu ditingkatkan lagi peran wali kelas dalam membentuk karakter siswa, bukan sekedar melaksanakan tugas sebagai wali kelas tetapi dengan sepenuh hati membimbing anak-anak kearah yang lebih baik. Lebih sering mengontrol siswa meskipun bukan pada jam pelajaran tetapi setiap pagi sebelum pelajaran dimulai sehingga akan terjalin ikatan emosional antara siswa dengan wali kelas.

Bagi Guru BK Guru BK harus lebih meningkatkan program-programnya dan bukan hanya melaksanakan program yang sudah ditetapkan di sekolah tetapi membuat program sendiri misalnya membuka layanan konsultasi secara pribadi melalui hp agar anak-anak lebih terbuka. Memperhatikan anak-anak yang bermasalah tetapi juga memperhatikan anak-anak yang berprestasi agar dapat diarahkan lebih baik.

Bagi Orang Tua Orang tua lebih meningkatkan kesadaran bahwa tanggung jawab perkembangan anak di sekolah bukan hanya tanggung jawab pihak sekolah saja tetapi tanggung jawab bersama antara orang tua dan sekolah. Lebih mengawasi pendidikan 
anak di rumah agar dapat mengetahui jika ada masalah yang terjadi pada anak.

\section{DAFTAR PUSTAKA}

Abidin Ibnus Rusn, 2009, Pemikiran AlGhazali Tentang pendidikan, Yogyakarta, Pustaka Pelajar

Ahmadi Abu, 2010, Bimbingan Dan Konseling Di Sekolah, Jakarta , PT. Pustaka

Ahmad Syarif dkk, 2011, Implementasi Pendidikan Karakter di SMK Berbasis Pesantren Syubbanul Wathon Tegalrejo Magelang, Jurnal Pendidikan Karakter, Volume 7 No. 5, diakses : 12 Juli 2018

Anwar, Sanusi. 2014. Metodologi Penelitian Bisnis. Jakarta: Salemba Empat

bimbingan dan konseling dalam jalur pendidikan formal 2007

Eva Imania, 2013, Peran Bimbingan dan Konseling Dalam Pendidikan Karakter Siswa (Kajian Psikologis Berdasarkan Teori Sistem Ekologis), Jurnal Pendidikan Bimbingan Konseling Vol. 12 No. 6, diakses : 16 Agustus 2018

Guba, 2010, The Paradigma Dialog, Newbury Park

Gunarsa Singgih D. 2006, Psikologi untuk Keluarga, Jakarta : Gunung Mulia

Jarvis Via Yamin, 2007, Teori-teori Psikologi : Pendekatan Modern untuk Memahami Perilaku, Perasaan dan Pikiran Manusia, Bandung, Nusa Media
Kartini Kartono, 2010, Peranan

Keluarga Memandu Anak, Sari Psikologi Terapan, Jakarta : Rajawali Press

Kemendiknas, 2010, Pendidikan Karakter Terintegrasi Dalam Pembelajaran di Sekolah Menengah Pertama, Jakarta, Direktorat PSMP Kemdiknas

Kertajaya, 2010, Pendidikan Karakter, Jakarta, Kompas Gramedia

Koesoema A. Doni, 2007, Pendidikan Karakter Strategi Pendidikan Anak di Zaman Global, (Jakarta: Grasindo

Lickona, 2014, Educating for Character - Bagaimana Sekolah dapat Memberikan Pendidikan Tentang Sikap Hormat dan Tanggung Jawab, Bandung, Bumi Aksara

Moleong J Lexy, 2012, Metodologi Penelitian Kualitatif, Bandung, Remaja Rosdakarya

Miles dan Huberman, 2013, Analisis Data Kualitatif Buku Sumber Tentang Metode-metode Baru. Jakarta: UIP

Mulyasa, 2007, Peranan Guru Dalam Pembelajaran, Bandung, Remaja Rosdakarya.

Nasution, 2006, Metode Penelitian Naturalistik Kualitatif. Bandung: Tarsito

Notoatmodjo Soekidjo, 2012, Ilmu Kesehatan Masyarakat, PT. Rineka Cipta, Jakarta 
Prayitno dan Erman Amti, 2012, DasarDasar Bimbingan dan Konseling, Jakarta: Rineka Cipta

Romayah Nur Puspitasari, 2017, Peran Wali Kelas Sebagai Bimbingan Konseling Menanamkan Karakter Disiplin dan Jujur Pada Siswa Kelas Tinggi SDN 2 Kadipiro Tahun Ajaran 2016/2017, Jurnal Bimbingan Konseling Vol. 3 Hal. 73-75

Sardiman, 2009, Media Pendidikan, Jakarta, PT. Raja Grafindo Persada

Sofan Amri, dkk, 2011, Proses Pembelajaran Kreatif dan Inovatif Dalam. Kelas: Metode, Landasan Teoritis-Praktis dan Penerapannya. Jakarta: PT. Prestasi. Pustakaraya

Sri Hartini, 2011, Pendidikan Karakter Disiplin Siswa di Era Modern Sinergi Orang Tua dan Guru di MTs Negeri Kabupaten Klaten, Journal Basic Of Education, Vo. 02 No. 02, ISSN : 25480002

Sugiyono, 2013, Metode Penelitian Pendidikan, Pendekatan Kuantitatif, Kualitatif, R dan D, Bandung, Alfabeta
Sukardi Dewa Ketut, 2008, Proses Bimbingan Dan Konseling Di Sekolah, Jakarta: Rineka Cipta

Suparlan, 2008, Wawasan pendidikan: Sebuah Pengantar Pendidikan. Yogyakarta: Ar-Ruzzmedia

Suyanto, 2009, Menjadi Guru Profesional strategi meningkatkan kualifikasi dan kualitas guru di Era Global, Jakarta : Erlangga

Takdiroatun Musfiroh, 2008, Cerdas Melalui Bermain. Jakarta: Grasindo

Tri Aulia Rahmawati, 2016, Upaya Guru Bimbingan Konseling Dalam Membentu Karakter Siswa di MTs. Negeri Yogyakarta II, Digital Library UIN Sunan Kalijaga

W.S Winkel, 2004, Bimbingan Dan Konseling Di Institusi Pendidikan, Jakarta: PT. Grasindo

Zuriah, 2013, Pendidikan Moral dan Budi Pekerti Dalam Perspektif Perubahan, Jakarta, PT. Bumi Aksara

Beck, A. T. (1993). Cognitive Therapy:

Past, Present, and Future. Journal of Consulting and Clinical $P$ 